UDC 665:664.3

\author{
P.O. Nekrasov, O.M. Gudz, O.P. Nekrasov, T.O. Berezka
}

\title{
OPTIMIZING THE PARAMETERS OF THE PRODUCTION PROCESS OF FAT SYSTEMS WITH A MINIMUM CONTENT OF TRANS-ISOMERS
}

\begin{abstract}
National Technical University «Kharkiv Polytechnic Institute», Kharkiv, Ukraine
Currently, the vast majority of solid fats, which are used as formula components of food products, are produced in Ukraine by partial hydrogenation. This method of fats modification leads to the formation of a significant amount of trans-isomers of fatty acids, which negatively affects the human body. It is known that the increased content of these isomers in the composition of fat products results in an increased risk of developing cardiovascular and metabolic diseases. In particular, the action of high-density lipoproteins is blocked, the deposition of cholesterol plaques on the walls of human blood vessels is initiated, and the development of atherosclerosis is provoked. We suggest resolving this problem by using interesterification of fats under the action of lipases, which has some advantages as compared with traditional technology. For instance, alkaline agents will not be used for catalysis, the reaction products will not be contaminated with catalysts, soaps will not be formed as by-products, the temperature of the process will be almost halved, and the organization of production will be less complicated and cheaper. The purpose of the work was to determine the rational parameters of the interesterification reaction aimed at the synthesis of fat systems with a minimum content of trans-isomers. The research objective was achieved by using the response surface methodology. The kinetics of reaction was studied by pulsed nuclear magnetic resonance. The processing and analysis of experimental data was performed by means of the Statistica 10 package. As a result of investigations, a mathematical model was developed that allows predicting the degree of conversion of starting materials into reaction products based on the data on the conditions of the interesterification process. Rational values of the main parameters for the synthesis of fatty systems with a minimum content of trans-isomers of fatty acids were specified. The obtained results can serve as a scientific basis for the development of technology for the production of fat systems with improved quality and safety characteristics.
\end{abstract}

Keywords: interesterification, fat, trans-isomer, mathematical modeling, optimization.

DOI: $10.32434 / 0321-4095-2020-130-3-128-133$

\section{Introduction}

In recent years, a new concept of nutrition has been worldwide developed. This concept implies not only a pleasant taste of food but also its safety and usefulness for the human body. In all developed countries, this issue is considered in the rank of public policy.

Taking into consideration a significant increase in morbidity among the population of Ukraine and the dominance of the food factor in the pathogenesis of diseases, one of the most pressing social problems of our time is the development of new domestic food technology aimed at protecting and maintaining human health $[1,2]$.
Currently, oil and fat industry in Ukraine produces a wide range of special fats intended for the confectionery, bakery, dairy, and other food industries. The vast majority of these fats contain undesirable spatial isomers of natural unsaturated fatty acids (trans-isomers). The results of many studies have shown that trans-isomers of fatty acids disrupt the functioning of enzymes and cell membranes in the human body, increase blood cholesterol and raise the risk of heart disease [3,4]. A high content of trans-isomers (up to 60\%) is found in edible hydrogenated fats, which are produced by partial hydrogenation of vegetable oils [5]. Food products made of such hydrogenated fats are not plastic 
enough and, as a rule, have a large-crystalline structure that is unstable during storage.

These shortcomings can be overcome by the use of the process of interesterification to modify fatty raw materials. In this case, completely hydrogenated fats and solid natural fats, such as palm, palm kernel and coconut oils, mixed with liquid oils can be used as raw materials. The interesterification of these mixtures not only reduces the content of the high-melting fraction of triacylglycerols, but also significantly increases the number of different triacylglycerols in the fat system, stimulates its crystallization into a $\beta$ '-polymorphic form, which is desirable for many foods.

Today, interesterification of fats on an industrial scale is carried out under the action of alkaline catalysts at high temperatures (up to $120^{\circ} \mathrm{C}$ ). The disadvantages of this process are contamination of the reaction products by the catalyst and the formation of soaps as by-products [6].

The use of interesterification under the catalytic effect of lipases instead of the traditional one has a number of advantages. They are as follows: mild reaction conditions (temperature of $65-70^{\circ} \mathrm{C}$ and atmospheric pressure); a subsequent bleaching or washing are not required; it is possible to adjust the degree of interesterification; natural substances are used that do not pollute the environment; organization of production is less complex and cheaper. Another important advantage is the ability to obtain edible fats with a natural distribution of acyls in acylglycerol molecules [7]. It is known that there are mainly acyls of unsaturated acids in the second position in acylglycerols, which are found in natural fats [8]. With interesterification by lipases, this natural distribution remains. Therefore, during digestion of both natural and modified fats in this way, the same elements of fat components enter the blood from the intestines [9].

Currently, the main difficulties on the way to the widespread dissemination of this technology are as follows: insufficiently deep knowledge of the process (as compared with traditional methods); still relatively high cost of the catalyst used; and insufficient awareness and lack of systemic experience with this technology in domestic enterprises.

The aim of our study was to determine the rational parameters of the interesterification reaction, aimed at the synthesis of fat systems with a minimum content of trans-isomers, which will be further used as formula components of high-quality food products.

Experimental

In order to study the interesterification of fats, high-oleic sunflower oil, which served as a supplier of monounsaturated fatty acids, and fully hydrogenated rapeseed oil, were used as a starting material. A feature of these components is an almost complete absence of trans-isomers of fatty acid in their composition. Furthermore, the use of higholeic sunflower oil instead of the traditional one is aimed at increasing the oxidative stability of the final product.

For optimization, the response surface methodology was used. This methodology [10] is a combination of mathematical and statistical techniques aimed at modeling processes and finding the combinations of experimental series of predictors in order to optimize the response function, which is generally described by the following polynomial:

$$
\begin{aligned}
& \hat{y}(x, b)=b_{0}+\sum_{l=1}^{n} b_{1} x_{1}+\sum_{k=1}^{n} b_{k} x_{k}^{2}+ \\
& +\sum_{i=1}^{n-1} \sum_{j=i+1}^{n} b_{i j} x_{i} x_{j}
\end{aligned}
$$

where $\mathrm{x} \in \mathrm{R}^{\mathrm{n}}$ is the vector of variables and $\mathrm{b}$ is the vector of parameters.

The unknown values of the parameter vector, b, were determined by using the algorithms of regression analysis and optimization (minimization) of the deviation functional (2):

$$
J(x)=\sum_{i=0}^{m}\left\|y_{i}-\hat{y}(x, b)\right\|^{2}
$$

where $\mathrm{m}$ is the amount of experimental data (y).

A central composite rotatable design was used in our study.

The degree of conversion of fatty raw materials (DC, \%), which was specified by changing the solid fat content at $40^{\circ} \mathrm{C}(\triangle \mathrm{SFC})$ and determined according to the equation (3), was selected as the optimization criterion.

$$
\mathrm{SFC}=\frac{\Delta \mathrm{SFC}_{\mathrm{i}}}{\Delta \mathrm{SFC}_{\infty}} \cdot 100,
$$

where $\triangle \mathrm{SFC}_{\infty}$ is the difference between the solid fat content at $40^{\circ} \mathrm{C}$ in the initial fat mixture and the solid fat content at $40^{\circ} \mathrm{C}$ in the interesterification product under conditions when the system reaches equilibrium; $\triangle \mathrm{SFC}_{\mathrm{i}}$ is the difference between the solid fat content at $40^{\circ} \mathrm{C}$ in the initial fat mixture and the solid fat content at $40^{\circ} \mathrm{C}$ in the interesterification product under the specified conditions of the experiment (i). 
The analysis of the solid fat content in the samples was carried out using pulsed nuclear magnetic resonance. This method is based on measuring the attenuation of magnetic induction signals from protons of solid and liquid fat by means of pulsed nuclear magnetic resonance with automatic calculation and induction of the value of the solid fat content. A Minispec mq 40 pulsed NMR spectrometer (manufactured by Bruker, Germany), which had an operating frequency of $40 \mathrm{MHz}$, was used for the research. The samples were analyzed in accordance with ISO 8292:2008 in three parallels.

The interesterification process was performed under vacuum with constant stirring $(450 \mathrm{rpm})$. The reaction was carried out under the catalytic effect of Novozym 40086 enzyme (Novozymes, Denmark). This catalyst is a Rhizomucor miehei sn-1,3-specific lipase immobilized onto silica gel. The content of the catalyst in the reaction mixture was $10 \mathrm{wt} . \%$ (with respect to fats). Independent varied factors were temperature and duration of the process. The choice of the levels and factor variability intervals was conducted according to the results of our previous experiments: the temperature of the process varied from 55 to $75^{\circ} \mathrm{C}$ and the duration varied from 120 to 420 minutes.

\section{Results and discussion}

Regarding the process under study, the following response function, which has the form of a polynomial of the second stage, was selected:

$$
\mathrm{DC}=\mathrm{b}_{0}+\mathrm{b}_{1} \mathrm{t}+\mathrm{b}_{11} \mathrm{t}^{2}+\mathrm{b}_{2} \tau+\mathrm{b}_{22} \tau^{2}+\mathrm{b}_{12} \mathrm{t} \tau,
$$

where DC is the degree of conversion $(\%) ; b_{0}$ is a constant; $\mathrm{t}$ is the process temperature $\left({ }^{0} \mathrm{C}\right) ; \tau$ is the duration of the process (min); $b_{1}, b_{11}, b_{2}, b_{22}, b_{12}$ are the coefficients for each element of the polynomial.

The design matrix and experimental values of the response function are shown in Table 1.

The analysis of experimental data was performed by using the Statistica 10 package (StatSoft, Inc.). The following model equations were obtained:

$$
\begin{aligned}
& \mathrm{DC}=-147.37+7.01 \mathrm{t}-0.07 \mathrm{t}^{2}+0.12 \tau+ \\
& +0.01 \tau^{2}+0.01 \mathrm{t} \tau .
\end{aligned}
$$

In order to check the significance of the regression coefficients (5), the Pareto chart was constructed (Fig. 1).

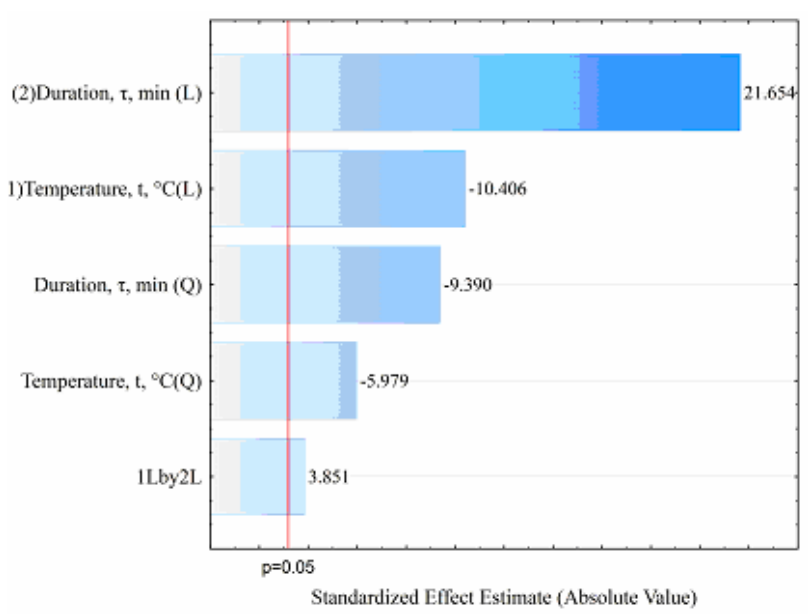

Fig. 1. Pareto chart ( $\mathrm{L}$ is the linear effect and $\mathrm{Q}$ is the quadratic effect)

The analysis of the data presented in Fig. 1

Design matrix and response function values

\begin{tabular}{c|c|c|c|c|c}
\hline \multirow{2}{*}{$\begin{array}{c}\text { Experiment } \\
\text { No. }\end{array}$} & \multicolumn{2}{|c|}{ Temperature, $\mathrm{t}$} & \multicolumn{2}{c|}{ Duration, } & \multirow{2}{*}{$\begin{array}{c}\text { Degree of } \\
\text { conversion (DC), } \%\end{array}$} \\
\cline { 2 - 5 } & Coded level & ${ }^{0} \mathrm{C}$ & Coded level & Minutes & 72.50 \\
\hline 1 & -1 & 58 & -1 & 164 & 87.20 \\
\hline 2 & -1 & 58 & +1 & 376 & 56.90 \\
\hline 3 & +1 & 72 & -1 & 164 & 82.50 \\
\hline 4 & +1 & 72 & +1 & 376 & 89.10 \\
\hline 5 & $-\sqrt{ } 2$ & 55 & 0 & 270 & 74.00 \\
\hline 6 & $+\sqrt{ } 2$ & 75 & 0 & 270 & 61.40 \\
\hline 7 & 0 & 65 & $-\sqrt{ } 2$ & 120 & 94.20 \\
\hline 8 & 0 & 65 & $+\sqrt{ } 2$ & 420 & 87.30 \\
\hline 9 & 0 & 65 & 0 & 270 & 86.50 \\
\hline 10 & 0 & 65 & 0 & 270 & 85.60 \\
\hline 11 & 0 & 65 & 0 & 270 & 84.00 \\
\hline 12 & 0 & 65 & 0 & 270 & \\
\hline
\end{tabular}


Model analysis of variance*

\begin{tabular}{l|c|c|c|c|c}
\hline \multicolumn{1}{c|}{ Factor } & $\begin{array}{c}\text { Sum of squares, } \\
\text { SS }\end{array}$ & $\begin{array}{c}\text { Degrees of } \\
\text { freedom, df }\end{array}$ & $\begin{array}{c}\text { Mean square value, } \\
\text { MS }\end{array}$ & F-value & $\begin{array}{c}\text { The level of } \\
\text { significance, } p \text {-value }\end{array}$ \\
\hline (1) Temperature (L) & 216.938 & 1 & 216.9384 & 108.2887 & 0.001894 \\
\hline Temperature (Q) & 71.610 & 1 & 71.6097 & 35.7453 & 0.009366 \\
\hline (2) Duration (L) & 939.353 & 1 & 939.3532 & 468.8951 & 0.000216 \\
\hline Duration (Q) & 176.621 & 1 & 176.6209 & 88.1635 & 0.002559 \\
\hline 1L by 2L & 29.703 & 1 & 29.7025 & 14.8265 & 0.030929 \\
\hline Lack of fit & 54.162 & 3 & 18.0539 & 9.0119 & 0.051953 \\
\hline Pure error & 6.010 & 3 & 2.0033 & - & - \\
\hline The total sum of squares & 1457.140 & 11 & - & - & - \\
\hline
\end{tabular}

Note: * Determination coefficient $\mathrm{R}^{2}=0.959$. Adjusted determination coefficient $\mathrm{R}_{\text {adj }}^{2}=0.924$.

shows that all columns cross a vertical line, which is a $95 \%$ confidence probability. Thus, we can conclude that all regression coefficients in Eq. (5) are significant.

The adequacy of the obtained model was checked by the analysis-of-variance method, the results of which are shown in Table 2.

The data shown in Table 2, in particular, the non-significant lack of fit (significance level $p>0.05$ ) and the values of the determination coefficients $\left(R^{2}\right.$ and $\mathrm{R}_{\text {adj }}^{2}$ ) which are close to 1 , allow us to conclude that the resulting model adequately describes the response.

The analysis of the critical points of regression (5) in the Statistica 10 environment made it possible to determine rational values of the parameters that correspond to the following maximum degree of conversion: temperature of $62^{\circ} \mathrm{C}$ and reaction time of $368 \mathrm{~min}$. This is confirmed by the graphic image (Fig. 2).

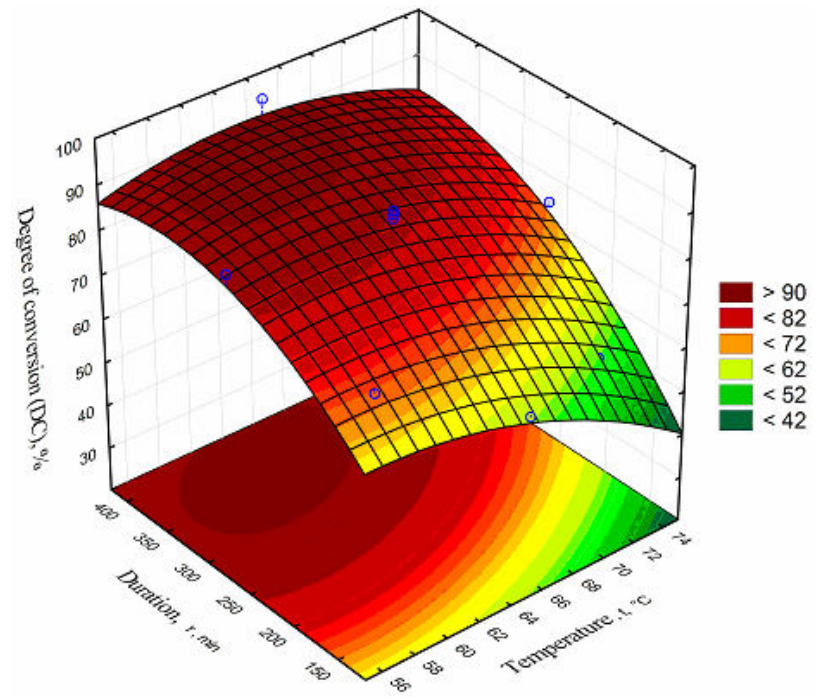

Fig. 2. Dependence of the degree of conversion of the initial fat mixture on the temperature and duration of the process
As can be observed, the highest values of the degree of conversion are observed in the temperature range of $60-64^{\circ} \mathrm{C}$ and the duration of the reaction is more than $300 \mathrm{~min}$.

A decrease in the interesterification effectiveness when rational temperatures and process duration are exceeded is explained by a corresponding decrease in lipase activity, which is due to the changes in its molecule conformation and partial denaturation of the apoenzyme and the inhibition of the enzyme by reaction products.

\section{Conclusions}

A mathematical model that allows predicting the degree of conversion of a starting material into interesterification products based on data on reaction parameters has been obtained.

Rational values of the main parameters for the synthesis of fatty systems with a minimum content of trans-isomers of fatty acids have been specified.

The obtained results will serve as a scientific basis for the development of technology for the production of fat systems with improved quality and safety characteristics.

\section{REFERENCES}

1. Kinetics and thermodynamics of biocatalytic glycerolysis of triacylglycerols enriched with omega-3 polyunsaturated fatty acids / Nekrasov P.O., Piven O.M., Nekrasov O.P., Gudz O.M., Kryvonis N.O. // Voprosy Khimii i Khimicheskoi Tekhnologii. - 2018. - No. 5. - P.31-36.

2. Optimization of formulation composition of the lowcalorie emulsion fat systems / Tkachenko N., Nekrasov P., Makovska T., Lanzhenko L. // East.-Eur. J. Enterprise Technol. - 2016. - Vol.81. - No. 3/11. - P.20-27.

3. Endoplasmic reticulum stress may be involved in insulin resistance and lipid metabolism disorders of the white adipose tissues induced by high-fat diet containing industrial trans-fatty 
acids / Zhu W., Niu X., Wang M., Li Z., Jiang H.-K., Li C., Caton S.J., Bai Y. // Diabetes, Metabolic Syndrome and Obesity: Targets and Therapy. - 2019. - Vol.12. - P.1625-1638.

4. Kwon $Y$. Effect of trans-fatty acids on lipid metabolism: mechanisms for their adverse health effects // Food Rev. Int. 2016. - Vol.32. - No. 3. - P.323-339.

5. Shahidi $F$. Bailey's industrial oil and fat products. Hoboken, New Jersey: John Wiley \& Sons, Inc., 2005. - 3616 p.

6. Casas A., Perez A., Ramos M. Catalyst removal after the chemical interesterification of sunflower oil with methyl acetate // Org. Process Res. Dev. - 2017. - Vol.21. - No. 9. - P.12531258.

7. Dijkstra A.J. Interesterification, chemical or enzymatic catalysis // Lipid Technol. - 2015. - Vol.27. - No. 6. - P.134136.

8. Sikorski Z., Koiakowska A. Chemical, biological and functional aspects of food lipids. - Boca Raton: CRC Press, Taylor \& Francis Group, 2011. - 512 p.

9. Moffatt R.J., Stamford B.A. Lipid metabolism and health. - Boca Raton: CRC/Taylor \& Francis, 2006. - 366 p.

10. Myers R., Montgomery D., Anderson-Cook C. Response surface methodology: process and product optimization using designed experiments. - Hoboken, New Jersey: John Wiley \& Sons, 2016. $-825 \mathrm{p}$.

Received 15.02.2020

\section{ОПТИМІЗАЦІЯ ПАРАМЕТРІВ ПРОЦЕСУ ВИРОБНИЦТВА ЖИРОВИХ СИСТЕМ 3 МІНІМАЛЬНИМ ВМІСТОМ ТРАНС-ІЗОМЕРІВ}

\section{П.О. Некрасов, О.М. Гудзь, О.П. Некрасов, Т.О. Березка}

В наш час в Україні переважна більшість твердих жирів, що використовуються як рецептурні компоненти харчових продуктів, виробляється методом часткової гідрогенізації. Цей метод модифікування жирів призводить до утворення у їх складі значної кількості транс-ізомерів жирних кислот, які негативно впливають на організм людини. Доведено, що підвищений вміст вказаних ізомерів у складі жирових продуктів призводить до підвищення ризику розвитку серцево-судинних захворювань, а також хвороб порушення метаболізму. Зокрема, блокується дія ліпопротеїдів високої шільності, ініціюється відкладення холестеринових бляшок на стінках кровоносних судин людини та провокується розвиток атеросклерозу. Авторами роботи пропонується вирішення вказаної проблеми шляхом використання переетерифікування жирів під дією ліпаз, що має низку переваг у порівнянні з традиційною технологією, а саме не використовуються для каталізу лужні агенти, не відбувається забруднення продуктів реакції каталізаторами, не утворюються мила як побічні продукти, майже вдвічі знижується температура перебігу процесу, організація виробниитва менш складна і більш дешева. Метою роботи було визначення раціональних параметрів реакції переетерифікування, спрямованого на синтез жирових систем з мінімальним вмістом транс-ізомерів. Задача дослідження вирішувалась з використанням методології поверхні відклику. Кінетику реакцій відстежували методом імпульсного ядерного магнітного резонансу. Обробку та аналіз експериментальних даних було виконано за допомогою пакета Statistica 10. В результати було розроблено математичну модель, яка дозволяє на основі даних щодо умов процесу переетерифікування прогнозувати ступінь перетворення вихідної сировини в продукти реакції. Встановлено раціональні значення основних параметрів синтезу жирових систем 3 мінімальним вмістом транс-ізомерів жсирних кислот. Отримані результати слугуватимуть науковим підгрунтям для розробки технології виробництва жирових систем з покращеними показниками якості та безпеки.

Ключові слова: переетерифікування, жир, транс-ізомер, математичне моделювання, оптимізація.

\section{OPTIMIZING THE PARAMETERS OF THE PRODUCTION PROCESS OF FAT SYSTEMS WITH A MINIMUM CONTENT OF TRANS-ISOMERS}

P.O. Nekrasov *, O.M. Gudz, O.P. Nekrasov, T.O. Berezka National Technical University «Kharkiv Polytechnic Institute», Kharkiv, Ukraine

\section{*e-mail: nekrasov2007@gmail.com}

Currently, the vast majority of solid fats, which are used as formula components of food products, are produced in Ukraine by partial hydrogenation. This method of fats modification leads to the formation of a significant amount of trans-isomers of fatty acids, which negatively affects the human body. It is known that the increased content of these isomers in the composition of fat products results in an increased risk of developing cardiovascular and metabolic diseases. In particular, the action of high-density lipoproteins is blocked, the deposition of cholesterol plaques on the walls of human blood vessels is initiated, and the development of atherosclerosis is provoked. We suggest resolving this problem by using interesterification of fats under the action of lipases, which has some advantages as compared with traditional technology. For instance, alkaline agents will not be used for catalysis, the reaction products will not be contaminated with catalysts, soaps will not be formed as by-products, the temperature of the process will be almost halved, and the organization of production will be less complicated and cheaper. The purpose of the work was to determine the rational parameters of the interesterification reaction aimed at the synthesis of fat systems with a minimum content of trans-isomers. The research objective was achieved by using the response surface methodology. The kinetics of reaction was studied by pulsed nuclear magnetic resonance. The processing and analysis of experimental data was performed by means of the Statistica 10 package. As a result of investigations, a mathematical model was developed that allows predicting the degree of conversion of starting materials into reaction products based on the data on the conditions of the interesterification process. Rational values of the main parameters for the synthesis of fatty systems with a minimum content of trans-isomers of fatty acids were specified. The obtained results can serve as a scientific basis for the development of technology for the production of fat systems with improved quality and safety characteristics.

Keywords: interesterification; fat; trans-isomer; mathematical modeling; optimization.

\section{REFERENCES}

1. Nekrasov P.O., Piven O.M., Nekrasov O.P., Gudz O.M., Kryvonis N.O. Kinetics and thermodynamics of biocatalytic glycerolysis of triacylglycerols enriched with omega-3 polyunsaturated fatty acids. Voprosy Khimii $i$ Khimicheskoi Tekhnologii, 2018, no. 5, pp. 31-36.

2. Tkachenko N., Nekrasov P., Makovska T., Lanzhenko L. Optimization of formulation composition of the low-calorie emulsion fat systems. Eastern-European Journal of Enterprise Technologies, 2016, vol. 81, no. 3/11, pp. 20-27. 
3. Zhu W., Niu X., Wang M., Li Z., Jiang H.-K., Li C., Caton S.J., Bai Y. Endoplasmic reticulum stress may be involved in insulin resistance and lipid metabolism disorders of the white adipose tissues induced by high-fat diet containing industrial transfatty acids. Diabetes, Metabolic Syndrome and Obesity: Targets and Therapy, 2019, vol. 12, pp. 1625-1638.

4. Kwon Y. Effect of trans-fatty acids on lipid metabolism: mechanisms for their adverse health effects. Food Reviews International, 2016, vol. 32, pp. 323-339.

5. Shahidi F., Bailey's industrial oil and fat products. John Wiley \& Sons, Hoboken, USA, 2005. 3616 p.

6. Casas A., Perez A., Ramos M.J. Catalyst removal after the chemical interesterification of sunflower oil with methyl acetate. Organic Process Research \& Development, 2017, vol. 21, pp. 1253-1258.

7. Dijkstra A.J. Interesterification, chemical or enzymatic catalysis. Lipid Technology, 2015, vol. 27, pp. 134-136.

8. Sikorski Z., Kolakowska A., Chemical, biological and functional aspects of food lipids. CRC Press, Taylor \& Francis Group, Boca Raton, 2011. 512 p.

9. Moffatt R.J., Stamford B.A., Lipid metabolism and health. CRC Taylor \& Francis, Boca Raton, 2006. 366 p.

10. Myers R., Montgomery D., Anderson-Cook C., Response surface methodology: process and product optimization using designed experiments. John Wiley \& Sons, Hoboken, USA, 2016. $825 \mathrm{p}$. 